\title{
Index-based Analysis of Georgian Wine Export's Competitiveness on a Global Market
}

\author{
Lasha Zivzivadze, Tengiz Taktakishvili \\ Department of Business Administration, Georgian National University (SEU), Tbilisi, Georgia \\ Email address: \\ 1.zivzivadze@yahoo.com (L. Zivzivadze), tengiztak@gmail.com (T. Taktakishvili)
}

\section{To cite this article:}

Lasha Zivzivadze, Tengiz Taktakishvili. Index-based Analysis of Georgian Wine Export's Competitiveness on a Global Market. International Journal of Agricultural Economics. Vol. 4, No. 5, 2019, pp. 201-206. doi: 10.11648/j.ijae.20190405.12

Received: June 21, 2019; Accepted: July 22, 2019; Published: August 5, 2019

\begin{abstract}
The main objective of the article is to determine competitiveness of Georgian wine exports. Initially, it is shown the current situation of Georgian wine export industry. In analysis part it is taken first 28 countries, where Georgia exports the wine and the period is defined from 2008-2018. In the methodological part, in order to determine competitiveness of Georgian wine it is used the Trade Intensity Index, Revealed Comparative Advantage Index (Balassa Index) and the competitiveness Index of Wine Exports between Georgia and other countries. Based on the results and discussion it should be concluded that Georgia has revealed comparative advantage in the international wine market. In the international market it is difficult for Georgia to compete large-volume wine production EU countries: France, Italy and Germany. The revealed comparative advantage for USA and Canada is low on the international wine market. However, it is hard for Georgia to compete with the USA wines on the international market, while Georgian wines are more competitive than Canadian.
\end{abstract}

Keywords: Georgian Wine, Wine Export, Export Competitiveness

\section{Introduction}

In Georgian agricultural sector, winemaking plays one of the leading roles, because of Georgia has 8,000 years history of wine production and more than 500 endemic varieties of vines. Georgia's agricultural development has untapped potential, including the development of the wine industry and its role in the development of the country's economy.

The main objective of the presented article is to determine competitiveness of Georgian wine exports and to identify the main trends in this direction. After introduction, the analysis of Georgian wine exports is presented and it is followed by a methodological part. The analysis of qualitative and quantitative methods used in the methodology provides results of the article. At the end of the article, the main conclusions are presented.

Various Georgian and foreign authors tried to research competitiveness of wine export on an international market also by using various indexes.

Natsvaladze, M., Kharaishvili, M., Chavleishvili, M. (2014) evaluated competitive advantages of Georgia to enter an international market. The level of competitiveness of Georgian wine is defined in the paper and evaluated by "ex- ante" and "ex-post" methods. The analysis of export demand for Georgian wine showed that there are main principle to be taken into consideration-meeting the requirements of international market. It has to be said that the authors didn't delve so deeply in analyzing of Georgia's export competitiveness while founding their conclusion regarding the issue only on the Index of Relative Export Advantage (RXA) [1].

COGEA S. R. L (2014) states that Georgia's wine exports may not be able to reach pre-ban levels as the Russian market has become more competitive since 2006, with stronger presence of local, Western European and South American wine brands. Similarly, wine exports from former USSR countries such as the Ukraine and the Republic of Moldova are only relevant for the Russian wine market [2]. We don't agree such a conclusion since Georgia can hold prominent position on niche markets in the world like one of bio-wine or natural wine and in the preceding article try to prove our argument using various competitiveness indexes.

Balogh and Ferto (2015) in there research have used several indexes for analysis of wine export competitiveness. Three of these indexes namely Additive Index of Revealed Comparative Advantage (ARCA), Relative Trade Advantage 
Index (RTA) and The Revealed Comparative Advantage (B) index Georgia, Moldova, Chile are the most competitive wine exporters [3].

Tsirekidze (2013) in his paper analyzed impact of Russian embargo on Georgian wine exporters. Author concludes that export barriers were driving force to open Georgian economy for very competitive European and US markets. He also finds that labor productivity and the quality of the products increased significantly during 2006-2013 Russian embargo [4].

Lombardi et al. (2016) compared exports of different classes of wine, creating the new "bottled wine" class made by the sum of two different HS 6 digit codes. They also assessed the "trend" effect in order to evaluate recent performances of the three main exporter countries. In their study authors use augmented version of the gravity model [5].

Beluhova-Uzunova R. and Roycheva A. (2017) tried to analyze the competitive advantages of viticulture of Bulgaria after the Accession. In the study they use several indicators for the evaluation of competitive advantages such as the Relative index of export advantages-RXA, the Relative trade advantage-RTA and Related competitiveness-RC [6].

Findings in these papers are interesting for our research. However, our study is the first one using three indexes for analysis of Georgian wine export's competitiveness: Trade Intensity Index, Revealed Comparative Advantage Index and Competitiveness Index of Wine Export between Georgia and Other Countries.

\section{Georgian Wine Export Industry Analysis}

As we have mentioned, wine industry development and wine exports are important for Georgia. The role of wine exports is even more important in recent years. For example, in 2008, the share of wine exports in the country's total exports was $2.5 \%$, and in 2018 , the same indicator was $5.9 \%$. In 2008, the share of wine exports in the country's total agricultural products was $14.7 \%$, and in 2018 , the same indicator was $20.5 \%$. Also, it is important to note that according to the data of 2018, the exports of wine, determined in value, is at the first place in exports of agricultural products.

In March 2006, Russian Federation imposed embargo on wine and wine products exported from Georgia, resulting in a sharp decline in wine export since 2006 [7]. However, Georgian wine-producing companies have begun searching for new markets, not to depend on one of the markets. From 2009 to 2012, Georgian wine exports recovered and began to grow, but the annual growth was not significant. In 2013, the export of wine was doubled and reached \$ 128 million, mainly due to the Russian Federation removal of embargo on Georgian export products. Wine export continued to growing until 2015, while wine export in 2015 decreased compared to 2014, because in 2014 Russian market was saturated with
Georgian wines. But market was recovered from 2016 and wine exports are significantly increased every year from 2016 to 2018.

Exports of Georgian wines have increased significantly since the independence of Georgia, including the last 11 years. Namely, in 2018, exports of Georgian wine amounted to about US 197 million, which is approximately 5.3 times higher than in 2008.

Furthermore, it is also vital to diversify Georgian wine export markets. According to the data of 2008, Georgian wine was exported in 39 countries, while in 2018, the same indicator has increased significantly and Georgian wine is exported in 57 countries. In 2008, the key exported countries for Georgian wine are: Ukraine $(52.6 \%)$, European Union (19.9\%), Kazakhstan (10.2\%), Belarus (9.2\%) and the USA (4\%). While in 2018, Georgian wine exported mainly in the following countries: Russian Federation (58.2\%), Ukraine (11\%), China (10.1\%), European Union (9.4\%) and Kazakhstan (4.5\%). It should be noted that exports of Georgian wine in European Union is mainly carried out in the following countries: Poland, Latvia, Germany, Estonia and Lithuania.

The main reasons for the significant growth of wine exports from Georgia over the last eleven years are the following factors: The strategic document of Georgian wine exports developed by the National Wine Agency, where the key objective is to increase the popularization of Georgian wine in the traditional and new markets and to stimulate Georgian wine exports; Increasing awareness of Georgian wine in the world - annually the Ministry of Environmental Protection and Agriculture supports Georgian wine companies to participate in international and local exhibitions; Exports diversification and positioning of Georgian wine at new markets; Improving Georgian wine quality; Georgia has Introduced Amber (Orange) wines and Georgian Qvevri wines (Unique and ancient organic production method) to the international markets [8]; Professor's conclusion about the 8,000-year history of Georgian wine and the discovery of the ancient ceramic vessel (Qvevri) in Georgia, which led to the recognition of "Georgia homeland of wine" in the world [9].

\section{Methodology and Data Collection}

In the methodological part for measuring competitiveness of wine export there are introduced three main indexes: Trade Intensity Index, Revealed Comparative Advantage Index and Competitiveness Index of Wine Export between Georgia and Other Countries. Let's explain each index in detail.

The Trade Intensity Index is used to determine the competitiveness. The Trade Intensity Index measures the intensity of trade between the two countries. This index was used by Kojima in 1964 [10].

The Trade Intensity Index is represented by the following formulas and variables:

$$
\mathrm{Ig}, \mathrm{i}=\frac{E X g, i}{E X g} \div \frac{I M i}{I M w}
$$


Where:

Ig, i - Trade Intensity Index between Georgia and i Country; EXg, i - Wine Export in i Country from Georgia;

EXg - Wine Export in World Countries from Georgia;

IMi - Wine Imports in i Country;

IMw - World Wine Imports.

In order to determine the competitiveness, Balassa introduced the Revealed Comparative Advantage Index (RCA) in 1965 [11], which was later used by different researchers [12, 13, 14]. The Balassa Index measures the country's ability to compete in the international market.

Revealed Comparative Advantage Index is represented by the following formulas and variables:

$$
R C A \mathrm{w}=\frac{E X i, w}{E X i, t} \div \frac{E X s ; i, w}{E X s ; i, t} \times 100
$$

Where:

RCAw - Revealed Comparative Advantage Index in Wine Exports;

EXi, w - Wine Exports from i Country;

EXi, $\mathrm{t}$ - Total Exports from i Country;

EXs; i, w - Sum of Wine Exports from Selected Countries Excluding Country i Wine Exports;

EXs; i, $\mathrm{t}$ - Sum of Total Exports from Selected Countries Excluding Country i Total Exports.

It is also crucial to use an index that shows the country's ability to compete with other countries, which have been used by the Diniz, Katsioloudes and Fortunas in 2006 [15].

The Competitiveness Index of Wine Exports between
Georgia and other countries is represented by the following formula and variables:

$$
C I g, \mathrm{i}=\frac{E X g, w}{E X w ; g, w} \div \frac{E X i, w}{E X w ; i, w}
$$

Where:

CIg, i - Wine Exports Competitiveness Index Between Georgia and Other Countries;

EXg, w - Wine Exports from Georgia;

EXw; g, w - World Wine Exports Excluding Georgian Wine Exports;

EXi, w - Wine Exports from i Country;

EXw; i, w - World Wine Exports Excluding Wine Exports from i Country.

In the presented article it is taken first 28 countries, where Georgia exports the wine. It should be noted that the variables are depicted in values, namely in US dollars. The trade data by countries are taken from COMTRADE's official online site. In the article, the variables are defined from 2008 to 2018 . Therefore, it has been analyzed for eleven years.

\section{Results and Discussion}

If the trade intensity index is higher than one, it shows strong trade relations between the two countries. And if the trade intensity index is less than one then it shows the weak trade relations between the two countries.

\begin{tabular}{|c|c|c|c|c|c|c|c|c|c|c|c|c|}
\hline & & 2008 & 2009 & 2010 & 2011 & 2012 & 2013 & 2014 & 2015 & 2016 & 2017 & 2018 \\
\hline 1 & Russian Federation & 0.13 & 0.00 & 0.00 & 0.00 & 0.01 & 12.70 & 19.21 & 21.25 & 22.01 & 20.16 & - \\
\hline 2 & Ukraine & 196.32 & 225.69 & 190.84 & 132.79 & 134.18 & 65.92 & 42.12 & 47.48 & 41.84 & 35.01 & 9.43 \\
\hline 3 & China & 0.39 & 1.00 & 0.62 & 0.85 & 1.24 & 0.58 & 0.61 & 1.44 & 1.70 & 1.50 & - \\
\hline 4 & Kazakhstan & 107.81 & 115.66 & 105.16 & 218.21 & 127.03 & 74.28 & 58.57 & 121.50 & 77.35 & 31.55 & - \\
\hline 5 & Poland & 6.75 & 8.33 & 7.45 & 6.01 & 6.29 & 3.39 & 3.30 & 5.62 & 5.58 & 4.21 & - \\
\hline 6 & Belarus & 50.92 & 59.04 & 53.66 & 63.48 & 53.00 & 24.74 & 21.85 & 23.37 & 20.86 & 15.92 & 3.88 \\
\hline 7 & Latvia & 34.51 & 26.62 & 29.97 & 24.04 & 23.99 & 11.74 & 6.28 & 12.75 & 9.62 & 6.56 & 2.00 \\
\hline 9 & Germany & 0.13 & 0.17 & 0.16 & 0.15 & 0.11 & 0.05 & 0.05 & 0.10 & 0.08 & 0.08 & - \\
\hline 10 & Estonia & 8.18 & 8.93 & 5.45 & 6.87 & 6.07 & 3.07 & 2.19 & 5.64 & 5.78 & 3.27 & 0.93 \\
\hline 11 & Azerbaijan & 180.13 & 803.04 & 422.20 & 871.61 & 298.06 & 152.56 & 137.63 & 229.51 & 36.41 & 33.02 & - \\
\hline 12 & Lithuania & 8.34 & 10.89 & 6.11 & 6.10 & 4.24 & 1.95 & 1.29 & 2.64 & 2.41 & 0.82 & 0.27 \\
\hline 13 & Japan & 0.08 & 0.14 & 0.14 & 0.10 & 0.11 & 0.08 & 0.08 & 0.14 & 0.14 & 0.11 & - \\
\hline 14 & Singapore & 0.00 & 0.26 & 0.00 & 0.05 & 0.00 & 0.00 & 0.10 & 0.06 & 0.16 & 0.16 & - \\
\hline 15 & Kyrgyzstan & 4.99 & 61.83 & 57.39 & 104.07 & 55.52 & 27.10 & - & 88.42 & 90.16 & 33.85 & 12.53 \\
\hline 18 & Israel & 11.10 & 9.97 & 6.81 & 5.90 & 3.01 & 1.62 & 1.57 & 2.87 & 2.20 & 2.34 & 0.68 \\
\hline 19 & United Kingdom & 0.03 & 0.02 & 0.01 & 0.03 & 0.02 & 0.01 & 0.02 & 0.05 & 0.06 & 0.02 & 0.01 \\
\hline 20 & France & 0.16 & 0.01 & 0.01 & 0.00 & 0.01 & 0.03 & 0.02 & 0.07 & 0.08 & 0.06 & - \\
\hline 21 & Netherlands & 0.05 & 0.10 & 0.27 & 0.21 & 0.10 & 0.17 & 0.28 & 0.32 & 0.16 & 0.14 & - \\
\hline 22 & China, Hong Kong & 0.00 & 0.15 & 0.00 & 0.04 & 0.10 & 0.02 & 0.03 & 0.06 & 0.02 & 0.02 & 0.01 \\
\hline 23 & Armenia & 102.96 & 235.95 & 113.01 & 100.87 & 63.49 & 50.70 & 32.85 & 32.81 & 39.63 & 22.54 & 7.19 \\
\hline 24 & Czech Republic & 0.79 & 0.34 & 0.25 & 0.03 & 0.15 & 0.03 & 0.06 & 0.12 & 0.46 & 0.10 & 0.54 \\
\hline 25 & Denmark & 0.00 & 0.00 & 0.00 & 0.00 & 0.00 & 0.00 & 0.00 & 0.01 & 0.03 & 0.00 & 0.01 \\
\hline 26 & South Korea & 0.78 & 0.43 & 0.00 & 0.00 & 0.12 & 0.00 & 0.08 & 0.11 & 0.03 & 0.06 & - \\
\hline 27 & Italy & 0.23 & 0.34 & 0.02 & 0.00 & 0.06 & 0.03 & 0.01 & 0.05 & 0.03 & 0.01 & - \\
\hline 28 & Bulgaria & 0.65 & 0.74 & 4.08 & 1.78 & 1.33 & 0.27 & 0.08 & 0.51 & 0.59 & 0.49 & - \\
\hline
\end{tabular}

Table 1. Results of Trade Intensity Index.

Source: Authors' Calculation 
As we know, in 2006, Russian Federation imposed embargo on Georgia and as a result, in 2006-2012, wine trade relations between the two countries dramatically reduced. As soon as Russian Federation has lifted embargo on agricultural products, since 2013 the trade intensity has increased sharply between the two countries (See Table 1).

In 2008-2012, wine trade intensity indicator between Ukraine and Georgia were high. Similar indicator between
Ukraine and Georgia has declined significantly in 2013 and has been characterized decreasing tendency until 2018.

Georgia has strong wine trade intensity with the following countries: Ukraine, Kazakhstan, Belarus, Latvia, Azerbaijan and Armenia. At the same time, Georgia has weak wine trade intensity with the following countries: USA, Germany, Japan, Singapore, United Kingdom, France, Netherlands, Hong Kong, Czech Republic, Denmark, South Korea and Italy.

Table 2. Results of Revealed Comparative Advantage Index.

\begin{tabular}{|c|c|c|c|c|c|c|c|c|c|c|c|c|}
\hline & & 2008 & 2009 & 2010 & 2011 & 2012 & 2013 & 2014 & 2015 & 2016 & 2017 & 2018 \\
\hline 1 & Russian Federation & 0.26 & 0.31 & 0.27 & 0.22 & 0.25 & 0.29 & 0.38 & 0.98 & 1.52 & 1.10 & - \\
\hline 2 & Ukraine & 41.30 & 83.27 & 65.93 & 34.17 & 39.06 & 65.68 & 33.28 & 49.93 & 31.89 & 39.22 & 56.33 \\
\hline 3 & China & 0.63 & 0.24 & 0.69 & 0.51 & 1.62 & 0.72 & 2.33 & 7.28 & 9.93 & 7.45 & - \\
\hline 4 & Kazakhstan & 0.34 & 0.34 & 0.06 & 0.02 & 0.02 & 0.02 & 0.53 & 4.27 & 3.01 & 0.55 & - \\
\hline 5 & Poland & 0.96 & 1.64 & 2.22 & 2.78 & 2.69 & 2.52 & 2.48 & 1.57 & 2.44 & 2.83 & - \\
\hline 6 & Belarus & 0.29 & 1.41 & 1.72 & 1.35 & 1.89 & 2.66 & 5.27 & 10.22 & 13.11 & 13.59 & 19.68 \\
\hline 8 & USA & 35.51 & 37.28 & 42.68 & 43.76 & 43.49 & 46.70 & 42.83 & 47.50 & 47.26 & 41.96 & - \\
\hline 9 & Germany & 36.34 & 40.62 & 44.41 & 44.17 & 44.03 & 44.79 & 41.69 & 37.47 & 33.60 & 34.59 & - \\
\hline 10 & Estonia & 98.32 & 95.79 & 92.61 & 64.68 & 53.77 & 50.54 & 53.91 & 52.13 & 75.15 & 89.53 & 113.98 \\
\hline 11 & Azerbaijan & 3.27 & 8.14 & 10.12 & 11.60 & 15.59 & 14.56 & 14.27 & 15.37 & 18.25 & 20.54 & - \\
\hline 12 & Lithuania & 140.24 & 151.32 & 211.95 & 221.10 & 280.14 & 348.86 & 345.99 & 256.57 & 251.06 & 292.54 & 409.71 \\
\hline 13 & Japan & 0.14 & 0.19 & 0.25 & 0.17 & 0.11 & 0.10 & 0.10 & 0.12 & 0.10 & 0.29 & - \\
\hline 14 & Singapore & 45.11 & 34.20 & 40.24 & 44.60 & 54.28 & 49.98 & 56.03 & 61.85 & 62.81 & 59.89 & - \\
\hline 16 & Canada & 2.25 & 2.78 & 3.75 & 4.58 & 5.01 & 5.90 & 6.63 & 7.73 & 8.01 & 7.43 & - \\
\hline 17 & Mongolia & - & - & - & - & - & 0.00 & 0.09 & 0.15 & 0.13 & 0.44 & - \\
\hline 18 & Israel & 19.23 & 18.12 & 21.02 & 19.52 & 24.16 & 26.10 & 27.54 & 29.39 & 31.39 & 36.63 & 50.28 \\
\hline 19 & United Kingdom & 46.68 & 67.24 & 83.70 & 93.38 & 75.31 & 63.80 & 74.90 & 71.26 & 74.61 & 77.23 & 123.94 \\
\hline 20 & France & $1,754.84$ & $1,483.12$ & $1,581.98$ & $1,589.31$ & $1,727.72$ & $1,647.76$ & $1,611.72$ & $1,580.76$ & $1,470.71$ & $1,606.73$ & - \\
\hline 21 & Netherlands & 12.65 & 11.89 & 14.21 & 25.27 & 24.89 & 22.41 & 25.72 & 29.22 & 31.61 & 29.95 & - \\
\hline 22 & China, Hong Kong & 12.05 & 14.06 & 22.21 & 27.21 & 23.52 & 18.90 & 30.15 & 59.14 & 60.00 & 47.89 & 39.04 \\
\hline 23 & Armenia & 95.32 & 106.72 & 152.01 & 98.25 & 156.50 & 143.65 & 217.94 & 127.54 & 161.62 & 239.82 & 269.13 \\
\hline 24 & Czech Republic & 8.64 & 9.05 & 9.82 & 12.01 & 12.53 & 15.86 & 11.92 & 9.23 & 7.16 & 6.82 & 5.11 \\
\hline 25 & Denmark & 64.34 & 58.19 & 68.24 & 54.96 & 68.09 & 75.75 & 75.35 & 73.64 & 64.10 & 64.62 & 111.63 \\
\hline 26 & South Korea & 0.04 & 0.02 & 0.08 & 0.17 & 0.00 & 0.01 & 0.04 & 0.04 & 0.04 & 0.02 & - \\
\hline 27 & Italy & 684.90 & 808.47 & 838.77 & 815.23 & 845.88 & 895.35 & 895.70 & 876.68 & 859.10 & 864.26 & - \\
\hline 28 & Bulgaria & 256.16 & 209.47 & 164.01 & 122.59 & 123.52 & 107.36 & 96.22 & 81.60 & 64.92 & 60.35 & - \\
\hline
\end{tabular}

Source: Authors' Calculation

If the revealed comparative advantage index is higher than 100 , then this country has a comparative advantage in wine exports. And if the index is less than 100 then the country does not have a revealed comparative advantage in wine exports.

According to revealed comparative advantage index, Georgia has a comparative advantage in wine exports (See Table 2). It has the capability to compete with the wines of different countries on the international wine market.

Besides Georgia, the following countries has the revealed comparative advantages in international wine market: France, Italy, Latvia and Lithuania. France and Italy are characterized with stable revealed comparative advantage index. Exports of wine share in imports in Latvia and Lithuania are respectively 1 and 1.3 . In other words, this means that imported wines in these countries are re-exported to different countries.

It is noteworthy that from 2012 to 2018 , the revealed comparative advantage of Armenian wines grow in international wine market.

From 2008 to 2013, Bulgaria had a comparative advantage in wine exports. But from 2014 to 2018, the revealed comparative advantage index is characterized by a decreasing tendency and also, significantly decreased in 2018.

The other countries do not have a revealed comparative advantage in wine exports. The lowest comparative advantage index were revealed in the following countries: Russian Federation, Kazakhstan, Japan, Mongolia, South Korea and Poland (See Table 2). 
Table 3. Competitiveness of Wine Exports between Georgia and Other Countries.

\begin{tabular}{|c|c|c|c|c|c|c|c|c|c|c|c|c|}
\hline & & 2008 & 2009 & 2010 & 2011 & 2012 & 2013 & 2014 & 2015 & 2016 & 2017 & 2018 \\
\hline 1 & Russian Federation & 14.92 & 16.11 & 1.00 & 23.52 & 24.82 & 40.37 & 47.64 & 13.84 & 12.08 & 20.05 & - \\
\hline 2 & Ukraine & 0.69 & 0.47 & 1.00 & 1.20 & 1.27 & 1.57 & 5.17 & 2.52 & 4.63 & 4.80 & 5.03 \\
\hline 3 & China & 1.83 & 4.70 & 1.00 & 2.43 & 0.84 & 3.34 & 1.37 & 0.23 & 0.21 & 0.39 & - \\
\hline 5 & Poland & 11.46 & 6.87 & 1.00 & 5.30 & 6.96 & 12.59 & 17.16 & 15.49 & 11.03 & 12.83 & - \\
\hline 6 & Belarus & 200.04 & 52.14 & 1.00 & 50.01 & 39.18 & 66.09 & 48.84 & 17.59 & 17.42 & 20.60 & 20.40 \\
\hline 7 & Latvia & 0.52 & 0.82 & 1.00 & 0.87 & 0.94 & 1.81 & 1.72 & 1.51 & 1.56 & 1.62 & 1.90 \\
\hline 9 & Germany & 0.03 & 0.03 & 1.00 & 0.04 & 0.05 & 0.09 & 0.13 & 0.09 & 0.11 & 0.14 & - \\
\hline 10 & Estonia & 1.43 & 1.57 & 1.00 & 2.40 & 3.50 & 7.10 & 9.87 & 6.62 & 5.12 & 5.95 & 6.73 \\
\hline 11 & Azerbaijan & 12.29 & 13.10 & 1.00 & 9.15 & 9.19 & 18.84 & 29.93 & 27.57 & 32.52 & 28.91 & - \\
\hline 12 & Lithuania & 0.58 & 0.63 & 1.00 & 0.45 & 0.41 & 0.58 & 0.83 & 0.74 & 0.86 & 0.96 & 1.05 \\
\hline 13 & Japan & 16.24 & 13.37 & 1.00 & 18.44 & 35.07 & 84.60 & 128.30 & 60.58 & 74.85 & 38.54 & - \\
\hline 14 & Singapore & 0.12 & 0.16 & 1.00 & 0.15 & 0.15 & 0.31 & 0.39 & 0.22 & 0.25 & 0.36 & - \\
\hline 15 & Kyrgyzstan & 237.12 & 155.04 & 1.00 & 351.07 & 1567.43 & 1802.47 & - & 300.12 & 232.82 & 206.58 & 369.65 \\
\hline 16 & Canada & 1.79 & 1.72 & 1.00 & 1.31 & 1.44 & 2.34 & 2.84 & 1.46 & 1.66 & 2.53 & - \\
\hline 18 & Israel & 1.63 & 1.80 & 1.00 & 2.12 & 2.23 & 3.75 & 4.87 & 2.54 & 2.82 & 3.65 & 4.28 \\
\hline 19 & United Kingdom & 0.08 & 0.06 & 1.00 & 0.06 & 0.09 & 0.18 & 0.24 & 0.14 & 0.17 & 0.23 & 0.22 \\
\hline 20 & France & 0.00 & 0.00 & 1.00 & 0.00 & 0.00 & 0.01 & 0.01 & 0.01 & 0.01 & 0.01 & - \\
\hline 21 & Netherlands & 0.26 & 0.29 & 1.00 & 0.20 & 0.24 & 0.49 & 0.61 & 0.36 & 0.37 & 0.52 & - \\
\hline 22 & China, Hong Kong & 0.42 & 0.33 & 1.00 & 0.22 & 0.28 & 0.62 & 0.57 & 0.15 & 0.17 & 0.30 & 0.43 \\
\hline 23 & Armenia & 19.17 & 21.51 & 1.00 & 21.71 & 15.30 & 31.16 & 28.66 & 25.42 & 18.43 & 15.95 & 21.43 \\
\hline 24 & Czech Republic & 1.51 & 1.51 & 1.00 & 1.42 & 1.72 & 2.53 & 4.42 & 3.27 & 4.57 & 6.49 & 154.53 \\
\hline 25 & Denmark & 0.26 & 0.29 & 1.00 & 0.45 & 0.47 & 0.78 & 1.11 & 0.69 & 0.88 & 1.24 & 1.12 \\
\hline 26 & South Korea & 112.15 & 209.81 & 1.00 & 28.09 & 1244.34 & 1131.68 & 388.18 & 232.48 & 259.27 & 669.41 & - \\
\hline 27 & Italy & 0.01 & 0.01 & 1.00 & 0.01 & 0.01 & 0.02 & 0.02 & 0.01 & 0.01 & 0.02 & - \\
\hline 28 & Bulgaria & 0.33 & 0.45 & 1.00 & 0.81 & 1.04 & 2.07 & 3.29 & 2.28 & 3.10 & 4.29 & - \\
\hline
\end{tabular}

Source: Authors' Calculation

If the value of the wine export competitiveness index exceeds one then Georgia has a competitive advantage over the export of wine to the respective country and can compete with the international market. If the index is less than one then Georgia does not have competitiveness in wine exports to the respective country.

The results showed that it is hard for Georgia to compete in the international wine market for the following countries: France, Italy, Germany, Lithuania, United Kingdom, the Netherlands and the United States.

France, Italy, USA and Germany are key wine producers in the world. In addition, these countries wines are well aware in the international market.

In 2017, the share of wine imports in wine exports in Lithuania, United Kingdom and the Netherlands is high and it equals to 1.3, 5.7 and 4 respectively. In other words, this means that imported wines in these countries are re-exported to different countries. At the same time, it is noteworthy, that local wine production in Lithuania, the United Kingdom and the Netherlands is insignificant.

In the international wine markets Georgia is competing with countries such as Russian Federation, Ukraine, Poland, Belarus, Latvia, Estonia, Azerbaijan, Japan, Canada, Armenia and Czech Republic (See Table 3). In the international wine market, Georgia did not compete with Bulgaria in 2008-2011, but since 2012 the situation has changed and from 2012 to 2018 Georgia is competing with Bulgaria on international wine market.

Georgia had to compete with China on the international wine market. Although, in 2015-2017 the situation has changed, it is hard for Georgia to compete with the Chinese wines on the international wine market. It is noteworthy that since 2015 wine exports have increased significantly from China and has grown three times more than in 2014. Although, in 2017, the wine imports exceed the wine imports approximately 6.4 times. However, in recent years, China has grown vineyards, and according to the data of 2017 , China, after Spain $(967,000$ hectares), is the second largest country in vineyard cultivated area in the world, with 870,000 hectares.

\section{Conclusion}

In recent years, export of wine has significantly increased from Georgia to China and in 2018, the share of wine exports amounted to about $10 \%$ of the country's total agricultural exports. It is noteworthy that in 2015-2017, the wine trade intensity have increased between Georgia and China. China does not have a revealed comparative advantage over the international wine market. Despite this, in 2015-2017, it is hard for Georgia to compete with China on the international wine market. The main reason for this may be the fact that China is one of the largest producers of wine in the world. Furthermore, in 2015-2017 period, the wine export significantly increased from China to other countries, despite the fact that China is also the largest importer of wine. In addition, the importance of the development of the wine industry plays a key role for the Chinese government.

After 2012, Russian Federation has lifted embargo on Georgia. As a result, Georgian wine export has increased 
significantly in the Russian market. Since 2013, the wine trade intensity between the two countries has significantly increased. As it is known, Russian Federation has no revealed comparative advantage over the world wine market and Georgia competes with Russian Federation on the international wine market.

According to the data of 2018, export of wine from Georgia to EU countries is high and wine exports share approximately $9.4 \%$ of the country's total agricultural products. Georgia has high wine trade intensity form the EU countries such as Poland, Latvia, Estonia and Lithuania.

From the EU countries, France and Italy have the revealed comparative advantage in wine industry. It should be noted that in the international market it is difficult for Georgia to compete for the following EU countries: France, Italy, and Germany. All three of them belong to countries with large-volume wine production worldwide. Despite the fact that Germany has imported a large amount of wine, Germany is one of the largest producers of wine in the world. Also, it should be mentioned that these countries' wines are well aware in the international market.

Georgia has weak wine trade intensity with the USA and Canada. The revealed comparative advantage for USA and Canada is low on international wine market. However, it is hard for Georgia to compete with the USA wines on the international market, while Georgian wines are more competitive than Canadian. USA is one of the key wine producer and exporter in international market.

In recent years, Exports of Georgian wines have increased significantly since the independence of Georgia, including the last 11 years (2008-2018). Georgia has revealed comparative advantage in the international wine market.

\section{References}

[1] Kharaishvili Eteri., Marina Chavleishvili, and Marina Natsvaladze. 2014. Trends and Prospects for the Development of Georgian Wine Market. World Academy of Science, Engineering and Technology International Journal of Economics and Management Engineering Vol: 8, No: 10. 3267-3271.

[2] COGEA S. R. L. 2014. Study on the competitiveness of European wines, Final Report.
[3] Balogh, Jeremias and Ferto, Imre. 2015. Drivers of Export Competitiveness in Wine Sector, International Conference of Agricultural Economists.

[4] Tsirekidze, David. 2013. Trade Restrictions and Labor Productivity: Evidence from the Georgian Wine Industry, Stanford University.

[5] Lombardi Pasquale, Dal Bianco Andrea, Freda Roberto, Caracciolo Francesco and Cembaloa Luigi. 2016. Development and trade competitiveness of the European wine sector: A gravity analysis of intra-EU flows, Wine Economics and Policy, Volume 5, Issue 1, Pages 50-59.

[6] Beluhova-Uzunova, R. and Roycheva, A. 2017. Competitive Advantages of the Bulgarian Viticulure and Wine Sector after the Accession to the European Union. Trakia Journal of Sciences, Vol. 15, Suppl. 1, pp 324-329.

[7] Livny, Eric. Mack Ott and Karine Torosyan. 2007. Impact of Russian Sanctions on the Georgian Economy. I. Javakhishvili Tbilisi State University. Department for International Development. 1-40.

[8] Anderson, Kym. 2013. Is Georgia the Next "New" WineExporting Country? Journal of Wine Economics, Volume 8, Number 1, 2013, Pages 1-28.

[9] Curry, Andrew. 2017. Oldest Evidence of Winemaking Discovered at 8, 000-Year-Old Village. National Geographic.

[10] Kojima, Kiyoshi. 1964. The Pattern of International Trade among Advanced Countries. Hitotsuboshi Journal of Economics, Vol. 5. 16-36.

[11] Balassa, Bela. 1965. Trade Liberalization and Revealed Comparative Advantage. Manchester School of Economic and Social Studies, 33, 99-123.

[12] Karpavicius, Henrikas. 2007. Assessing Lithuania's Competitiveness in the Context of EU Enlargement. Ekonomika, 77, 25-34.

[13] Sevela, M. 2003. Efficiency Development of Foreign Trade in High-Technology Products and High-Value Agricultural Products. Agricultural Economics. 49. 2003 (10). 476-482.

[14] Widgren, Mika. 2005. Revealed Comparative Advantage in the Internal Market. ETLA Discussion Paper. Helsinki. 1-20.

[15] Diniz Francisco J., Marios Katsioloudes, and Sandra P. Fortunas. 2006. The competitiveness of the Portuguese wine sector and a case study of exports and activity diversification in the Vinhos Verdes region. European Association of Agricultural Economists. 1-19. 